Ferrata Storti Foundation

\title{
Calreticulin exposure on malignant blasts correlates with improved natural killer cell-mediated cytotoxicity in acute myeloid leukemia patients
}

Haematologica 2020

Volume 105(7):1868-1878

\section{Correspondence: \\ JITKA FUCIKOVA \\ fucikova@sotio.com \\ Received: April 8, 2019. \\ Accepted: September 26, 2019. \\ Pre-published: October 3, 2019.}

doi:10.3324/haematol.2019.223933

Check the online version for the most updated information on this article, online supplements, and information on authorship \& disclosures: www. haematologica.org/content/105/7/1868

(C)2020 Ferrata Storti Foundation

Material published in Haematologica is covered by copyright. All rights are reserved to the Ferrata Storti Foundation. Use of published material is allowed under the following terms and conditions:

https://creativecommons.org/licenses/by-nc/4.0/legalcode. Copies of published material are allowed for personal or internal use. Sharing published material for non-commercial purposes is subject to the following conditions:

https://creativecommons.org/licenses/by-nc/4.0/leǵalcode, sect. 3. Reproducing and sharing published material for commercial purposes is not allowed without permission in writing from the publisher.
Iva Truxova, ${ }^{1}$ Lenka Kasikova, ${ }^{1,2}$ Cyril Salek, ${ }^{3,4}$ Michal Hensler, ${ }^{1}$ Daniel Lysak, ${ }^{5}$ Peter Holicek, ${ }^{1,2}$ Pavla Bilkova, ${ }^{1}$ Monika Holubova, ${ }^{6}$ Xiufen Chen, ${ }^{7}$ Romana Mikyskova, ${ }^{8}$ Milan Reinis, ${ }^{8}$ Marek Kovar, ${ }^{9}$ Barbora Tomalova, ${ }^{9}$ Justin P. Kline, ${ }^{7,10,11}$ Lorenzo Galluzzi, ${ }^{12,13,14,15,16}$ Radek Spisek ${ }^{1,2}$ and Jitka Fucikova ${ }^{1,2}$

${ }^{1}$ Sotio, Prague, Czech Republic; '2Department of Immunology, Charles University, $2^{\text {nd }}$ Faculty of Medicine and University Hospital Motol, Prague, Czech Republic; ${ }^{3}$ Institute of Hematology and Blood Transfusion, Prague, Czech Republic; ${ }^{4}$ Institute of Clinical and Experimental Hematology, $1^{\text {st }}$ Faculty of Medicine, Charles University, Prague, Czech Republic; ${ }^{5}$ Department of Hematology and Oncology, University Hospital in Pilsen, Czech Republic; ' Laboratory of Tumor Biology and Immunotherapy, Biomedical Center, Faculty of Medicine in Pilsen, Charles University, Pilsen, Czech Republic; ${ }^{7}$ Department of Medicine, University of Chicago, Chicago, IL, USA; ' Laboratory of Immunological and Tumour models, Institute of Molecular Genetics of the Czech Academy of Sciences, Prague, Czech Republic; 'Laboratory of Tumor Immunology, Institute of Microbiology of the Czech Academy of Sciences, Prague, Czech Republic; ${ }^{10} \mathrm{Committee}$ on Immunology, University of Chicago, Chicago, IL, USA; ${ }^{11}$ University of Chicago Comprehensive Cancer Center, Chicago, IL, USA; ${ }^{12}$ Department of Radiation Oncology, Weill Cornell Medical College, New York, NY, USA; ${ }^{13}$ Sandra and Edward Meyer Cancer Center, New York, NY, USA; ${ }^{14}$ Caryl and Israel Englander Institute for Precision Medicine, New York, NY, USA; ${ }^{15}$ Department of Dermatology, Yale School of Medicine, New Haven, CT, USA and ${ }^{16}$ Universite de Paris, Paris, France

\section{ABSTRACT}

Tn some settings, cancer cells responding to treatment undergo an immunogenic form of cell death that is associated with the abundant emission of danger signals in the form of damage-associated molecular patterns. Accumulating preclinical and clinical evidence indicates that danger signals play a crucial role in the (re-)activation of antitumor immune responses in vivo, thus having a major impact on patient prognosis. We have previously demonstrated that the presence of calreticulin on the surface of malignant blasts is a positive prognostic biomarker for patients with acute myeloid leukemia (AML). Calreticulin exposure not only correlated with enhanced T-cell-dependent antitumor immunity in this setting but also affected the number of circulating natural killer (NK) cells upon restoration of normal hematopoiesis. Here, we report that calreticulin exposure on malignant blasts is associated with enhanced NK cell cytotoxic and secretory functions, both in AML patients and in vivo in mice. The ability of calreticulin to stimulate $\mathrm{NK}$-cells relies on $\mathrm{CD} 11 \mathrm{c}^{+} \mathrm{CD} 14^{\text {high }}$ cells that, upon exposure to CRT, express higher levels of IL-15R $\alpha$, maturation markers (CD86 and HLADR) and CCR7. CRT exposure on malignant blasts also correlates with the upregulation of genes coding for type I interferon. This suggests that CD11 $c^{+} \mathrm{CD} 14^{\text {high }}$ cells have increased capacity to migrate to secondary lymphoid organs, where can efficiently deliver stimulatory signals (IL-15Ra/IL$15)$ to NK cells. These findings delineate a multipronged, clinically relevant mechanism whereby surface-exposed calreticulin favors NK-cell activation in AML patients.

\section{Introduction}

In response to some treatments including anthracycline-based chemotherapy, high hydrostatic pressure or radiation therapy, cancer cells mount unsuccessful adaptive responses to stress that are accompanied by the release of endogenous 
molecules that convey danger signals, which are cumulatively known as damage-associated molecular patterns (DAMPs). ${ }^{1-4}$ The spatiotemporally regulated emission of DAMPs by cells undergoing immunogenic cell death (ICD) generates a pronounced immunostimulatory milieu that, in the presence of adequate antigenicity (such as that conferred to cancer cells by somatic mutations), supports the initiation of tumor-targeting immunity. ${ }^{2,5}$ ICD-relevant DAMPs encompass endoplasmic reticulum (ER) chaperones such as calreticulin (CALR, best known as CRT) and

Table 1. Clinical and biological characteristics of acute myeloid leukemia patients.

\begin{tabular}{|c|c|}
\hline Variable & Cohort $(n=50)$ \\
\hline $\begin{array}{l}\text { Age at diagnosis } \\
<50 \text { years } \\
\geq 50 \text { years } \\
\text { Median (years) } \\
\text { Range (years) }\end{array}$ & $\begin{array}{c}23(46 \%) \\
27(54 \%) \\
52 \\
21-73\end{array}$ \\
\hline $\begin{array}{l}\text { Sex } \\
\text { Male } \\
\text { Female }\end{array}$ & $\begin{array}{l}23(46 \%) \\
27(54 \%)\end{array}$ \\
\hline $\begin{array}{l}\text { White blood cell count at diagnosis } \\
<30.000 / \mathrm{mm}^{3} \\
\geq 30.000 / \mathrm{mm}^{3} \\
\text { Median }\left(10^{9} \text { cells/L) }\right. \\
\text { Range }\left(10^{9} \text { cells/L) }\right.\end{array}$ & $\begin{array}{c}42(84 \%) \\
8(16 \%) \\
6.9 \\
0-402.8\end{array}$ \\
\hline $\begin{array}{l}\text { Blasts in peripheral blood } \\
\text { Median (\%) } \\
\text { Range (\%) }\end{array}$ & $\begin{array}{c}25 \\
0-91\end{array}$ \\
\hline $\begin{array}{l}\text { De novo AML } \\
\text { Secondary AML }\end{array}$ & $\begin{array}{l}41(82 \%) \\
9(18 \%)\end{array}$ \\
\hline $\begin{array}{l}\text { FAB classification } \\
\text { M0 } \\
\text { M1 } \\
\text { M2 } \\
\text { M4 } \\
\text { M5 } \\
\text { M6 } \\
\text { MDS }\end{array}$ & $\begin{array}{c}1(2 \%) \\
10(20 \%) \\
12(26 \%) \\
7(14 \%) \\
10(20 \%) \\
1(2 \%) \\
8(16 \%)\end{array}$ \\
\hline $\begin{array}{l}\text { Cytogenetic profile } \\
\text { Favorable } \\
\text { Intermediate } \\
\text { Unfavorable } \\
\text { Missing data }\end{array}$ & $\begin{array}{l}6(12 \%) \\
29(58 \%) \\
8(16 \%) \\
7(14 \%)\end{array}$ \\
\hline $\begin{array}{l}\text { Molecular characteristics } \\
\text { FLT3-ITD } \\
\text { NPM1 mutated } \\
\text { CEBPA mutated }\end{array}$ & $\begin{array}{c}7(14 \%) \\
12(24 \%) \\
2(4 \%)\end{array}$ \\
\hline $\begin{array}{l}\text { Induction chemotherapy } \\
\text { Daunorubicin + Ara-C }(3+7) \\
\text { Idarubicin + Ara-C }(3+7) \\
\text { FLAG + Idarubicin } \\
\text { Palliative treatment } \\
\text { CR }\end{array}$ & $\begin{array}{c}38(76 \%) \\
10(20 \%) \\
1(2 \%) \\
1(2 \%) \\
40(80 \%)\end{array}$ \\
\hline $\begin{array}{l}\text { Consolidation } \\
\text { Chemotherapy only } \\
\text { HSCT } \\
\text { No consolidation }\end{array}$ & $\begin{array}{c}14(28 \%) \\
30(60 \%) \\
6(12 \%)\end{array}$ \\
\hline
\end{tabular}

AML: acute myeloid leukemia; AM1-ETO: acute myeloid leukemia 1-ETO fusion protein; CEBPA: CCAAT/enhancer-binding protein alpha; CR: complete remission; FLAG: fludarabine + high-dose cytarabine + granulocyte colony-stimulating factor (G-CSF); FLT3-ITD: fms-like tyrosine kinase 3-internal tandem duplication; HSCT: hematopoietic stem cell transplantation; MDS: myelodysplastic syndrome; NPM1: nucleophosmin 1. FAB: French-American-British. heat-shock proteins (HSPs), nuclear components such as high mobility group box 1 (HMGB1), nucleic acids, as well as small metabolites like ATP., In physiological scenarios, DAMPs are mostly intracellular, which prevents their detection by the immune system. Conversely, DAMPs that are secreted into the extracellular space or exposed on the plasma membrane of dying cancer cells can be recognized by the immune system via pattern recognition receptors (PRRs), and hence can drive the activation of therapeutically relevant innate and cognate immune responses. ${ }^{2,8}$ In line with this notion, DAMP accumulation in the tumor microenvironment has been correlated with increased infiltration by multiple immune cell subsets, including mature dendritic cells (DCs) and effector memory $\mathrm{T}$ cells. ${ }^{9-12}$ Moreover, factors linked to danger signaling - including (but not limited to) DAMPs expression levels, PRR expression levels, genetic polymorphisms in DAMPor PRR-coding genes, and activation of relevant stress responses in cancer cells - have been attributed prognostic values in several cohorts of patients with cancer. ${ }^{13}$

Considerable work has been dedicated to elucidate the mechanisms whereby DAMPs affect the phenotype and function of myeloid cells that operate as antigen-presenting cells (APCs), ${ }^{2,8}$ On the contrary, little attention has been given to the effects of DAMPs on cells of the innate lymphoid system, such as natural killer (NK) cells, despite the fact that NK cells are emerging as potent players in the control of metastases. ${ }^{14}$ Indeed, surface-exposed HSP family A member 1A (HSPA1A, best known as HSP70) promotes NK-cell-dependent cytotoxicity in vitro ${ }^{15,16}$ and in vivo, ${ }^{17}$ while exosome-associated HSP70 can stimulate NKcell migration and effector functions. ${ }^{18,19}$ Similarly, extracellular HMGB1 can stimulate NK-cell activity upon binding to Toll-like receptor 2 (TLR2) and TLR4. ${ }^{20}$ Here, we report that CRT exposure on the surface of malignant blasts from acute myeloid leukemia (AML) patients is associated with improved NK-cell secretory and cytotoxic functions. Mechanistic studies revealed that surfaceexposed CRT stimulates NK-cell activity indirectly, through the upregulation of IL-15R $\alpha$ on myeloid $\mathrm{CD} 11 \mathrm{c}^{+} \mathrm{CD} 14^{\text {high }}$ cells. Moreover, CRT exposure on AML malignant blasts also correlates with the upregulated expression of genes coding for type I interferon (IFN), which are also involved in the capacity of DCs to enhance NK-cell effector functions.

\section{Methods}

\section{Patients}

44 patients diagnosed with AML and treated at the Institute of Hematology and Blood Transfusion in Prague between December 2015 and March 2018 plus six AML patients diagnosed and treated at the Department of Hemato-oncology of the Pilsen Hospital between January 2017 and January 2018 were enrolled in this study. Informed consent was obtained according to the Declaration of Helsinki, and the study was approved by the local ethics committee. The main clinical and biological characteristics of the patients are summarized in Table 1. Induction chemotherapy consisted mainly $(96 \%)$ of seven days cytarabine plus idarubicin or daunorubicin for the first three days (standard " $7+3$ " regimen).

\section{Flow cytometry}

Peripheral blood mononuclear cell (PBMCs) isolated from AML patients or C57BL/6 (B6) mice, as well as mouse splenocytes, 
bone-marrow derived DCs and tumor cells were stained with panels of fluorescent antibodies to evaluate the abundance, phenotype and function of immune cell subsets (Online Supplementary Table S1-2). Briefly, cells were incubated with primary antibodies or appropriate isotype controls for $20 \mathrm{~min}$ at $4{ }^{\circ} \mathrm{C}$. For the analysis of CRT levels on AML blasts, PBMCs were labeled with antiCD45 PerCP (Exbio) and anti-CD33 PE monoclonal antibodies (BioLegend). Malignant blasts from AML patients were defined as CD $45^{+}$cells expressing high levels of CD33 (CD33 high). Surface CRT staining was performed by a three-step procedure: (1) incubation with primary CRT-specific antibody (Enzo Life Sciences), (2) incubation with an APC-conjugated secondary antibody (Jackson Immunoresearch Laboratories) and (3) incubation with Annexin V-FITC (Exbio) and 4',6-diamidino-2-phenylindole (DAPI, from Molecular Probes) to assess the cell viability. Surfaceexposed CRT levels were analyzed only on live $\left(\mathrm{AnnV}^{-} \mathrm{DAPI}^{-}\right)$and dying $\left(\mathrm{AnnV}^{+} / \mathrm{DAPI} \mathrm{I}^{-}\right)$but not dead $\left(\mathrm{DAPI}^{+}\right)$cells. Flow cytometry data were acquired on the LSRFortessa analyzer (BD Biosciences) and analyzed with the FlowJo software package (Tree Star, Inc.).

\section{Statistical analysis}

Survival analyses were performed by using log-rank tests upon patient stratification into two groups based on the median cutoff of continuous variables. Univariate and multivariate Cox proportional hazard analysis was performed to assess the association of clinicopathological or immunological parameters with relapse-free survival (RFS). Variables that were intrinsically correlated were not included in multivariate Cox regressions. Fisher's exact tests, Student's $t$-tests, and the Wilcoxon and Mann-Whitney tests were used to test for association between variables, $P$-values are reported (considered not significant when $>0.05$ ).

\section{Results}

\section{CRT exposure on malignant blasts is associated with increased NK-cell frequency and upregulation of ligands for activating NK-cell receptors}

We previously demonstrated a link between CRT exposure on malignant blasts and clinically-relevant anticancer immunity in AML patients. ${ }^{10}$ To extend these findings, we examined the potential impact of CRT on the plasma membrane (ecto-CRT) of $\mathrm{CD} 45^{+} \mathrm{CD} 33^{+}$malignant blasts on the frequency and phenotype of NK cells from AML patients prior to the initiation of anthracycline-based chemotherapy and at the recovery of normal hematopoiesis. Patients were stratified based on the median percentage of DAPI-ecto-CRT+ blasts at diagnosis into a CRT $T^{\mathrm{Hi}}$ and $\mathrm{CRT}^{\mathrm{Lo}}$ group. In baseline conditions (prior to induction chemotherapy), we were unable to identify statistically significant differences in the frequency and absolute numbers of circulating $\mathrm{CD}^{2} 5^{+} \mathrm{CD} 3^{-} \mathrm{CD}^{2} 6^{+} \mathrm{NK}$ cells between these two groups of patients (Figure 1A-B). Conversely, upon complete remission and recovery of nonmalignant hematopoiesis, CRT ${ }^{\mathrm{Hi}}$ AML patients had significantly higher frequency and absolute numbers of $\mathrm{CD} 45^{+} \mathrm{CD} 3^{-} \mathrm{CD} 56^{+} \mathrm{NK}$ cells in the circulation as compared to their CRT ${ }^{\mathrm{Lo}}$ counterparts (Figure 1A-B). These results are in line with previously published data from our group..$^{10}$ Of note, CRT ${ }^{\mathrm{Hi}} \mathrm{AML}$ patients did not display increased frequency of $\mathrm{CD} 45^{+} \mathrm{CD} 3{ }^{-} \mathrm{CD} 56^{+} \mathrm{NK}$ cells in the bone marrow as compared to their CRT ${ }^{\mathrm{LO}}$ counterparts (Online Supplementary Figure S1A).

As NK-cell activation is modulated by the balance between stimulatory and inhibitory signals delivered by multiple ligand/receptor interactions,${ }^{14}$ we next analyzed the levels of common activating (NKp30, NKp46, NKp80, NKG2D, DNAM-1 and CD16) and inhibitory (CD158e1, CD158bj, CD158ah, NKG2A, ILT2) NK-cell receptors by flow cytometry. With the exception of ILT2 ${ }^{+}$cells (which were less represented in the circulation of CRT ${ }^{\mathrm{Hi}} \mathrm{AML}$ patients upon remission), we failed to detect significant differences in the percentage of NK cells staining positively for these receptors between $C R T^{\text {Hi }}$ and CRT ${ }^{\text {Lo }} \mathrm{AML}$ patients, neither prior to induction chemotherapy nor upon complete remission (Figure 1C and Online Supplementary Figure S1B). Because CRT exposure relies on ER stress responses, ${ }^{21}$ and different stress response pathways may also modulate the expression of ligands for NK-cell receptors, ${ }^{22}$ we decided to evaluate the potential connection between CRT exposure and the levels of multiple NK-cell ligands on the surface of $\mathrm{CD}_{4} 5^{+} \mathrm{CD} 33^{+}$ blasts, namely major histocompatibility complex (MHC) class I polypeptide-related sequence A (MICA), MICB, UL16 binding protein 2 (ULBP2), ULBP5, ULBP6, poliovirus receptor (PVR, also known as CD155), nectin cell adhesion molecule 2 (NECTIN2, also known as CD112 and PVRL2), and B7-H6, by flow cytometry. We found that the percentage of DAPI-ecto-CRT ${ }^{+}$blasts positively correlates with the percentage of AML blasts staining positively for MICA, MICB, CD155 and CD112 (Figure 1D). In the attempt to identify a potential connection between the exposure of NK-cell-activating ligands (NKALs) and ER stress, we retrieved normalized MICA, ULBP2, PVR and NECTIN2 expression levels for 173 AML patients from The Cancer Genome Atlas (TCGA) public database and analyzed their correlation with the expression levels of genes involved in the ER stress response, namely activating transcription factor 4 (ATF4), DNA damage inducible transcript 3 (DDIT3) and HSP family A (Hsp70) member 5 (HSPA5). However, linear regression analysis showed limited degrees of correlation (Online Supplementary Figure S1C), suggesting the involvement of other stress response mechanisms in the exposure of NKALs by malignant blasts. Altogether, these findings indicate that malignant blasts from AML patients display different danger signals on their surface, and this influences the abundance of circulating NK cells.

\section{CRT exposure on malignant blasts correlates with improved NK-cell effector functions in AML patients in remission}

Since the ability of surface-exposed CRT to deliver activatory signals to NK cells had not been previously investigated, we set out to address this possibility. To this aim, we evaluated degranulation and IFN- $\gamma$ production by NK cells from $\mathrm{CRT}^{\mathrm{Hi}}$ and $\mathrm{CRT}{ }^{\mathrm{L} \mathrm{O}} \mathrm{AML}$ patients upon non-specific stimulation with phorbol 12-myristate 13-acetate (PMA) and ionomycin by flow cytometry (Online Supplementary Figure S1D). We failed to detect statistically significant differences in the frequency of NK cells responding to stimulation with IFN- $\gamma$ production (IFN- $\gamma^{+} \mathrm{CD} 45^{+} \mathrm{CD} 3-\mathrm{CD} 56^{+}$cells) and degranulation $\left(\mathrm{CD} 107 \mathrm{a}^{+} \mathrm{GZMB}{ }^{+} \mathrm{CD} 45^{+} \mathrm{CD} 3^{-} \mathrm{CD}^{2} 6^{+}\right.$cells) between $\mathrm{CRT}^{\mathrm{Hi}}$ and $\mathrm{CRT}^{\mathrm{Lo}} \mathrm{AML}$ patients prior to induction chemotherapy (Figure 2A). On the contrary, upon remission and recovery of non-malignant hematopoiesis, $\mathrm{CRT}^{\mathrm{Hi}}$ patients exhibited significantly improved NK-cell secretory and cytotoxic effector functions compared to 
their CRT ${ }^{\text {Lo }}$ counterparts (Figure $2 \mathrm{~B}$ ). To evaluate NK-cell effector functions in a more direct manner, we also performed NK-cell cytotoxicity assays using NK cell-sensitive human chronic myelogenous leukemia K562 cells as targets. In general, NK cells isolated from AML patients at recovery had slightly higher cytotoxic functions than NK cells isolated from AML patients prior to induction chemotherapy (Figure 2C). Importantly, while surfaceexposed CRT failed to affect the ability of NK cells isolated from AML patients prior to the initiation of treatment
A

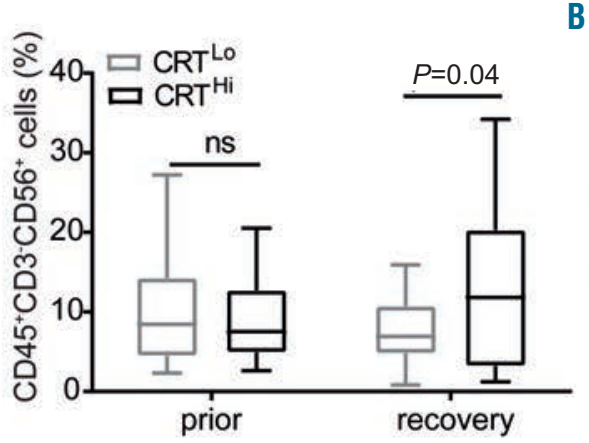

C

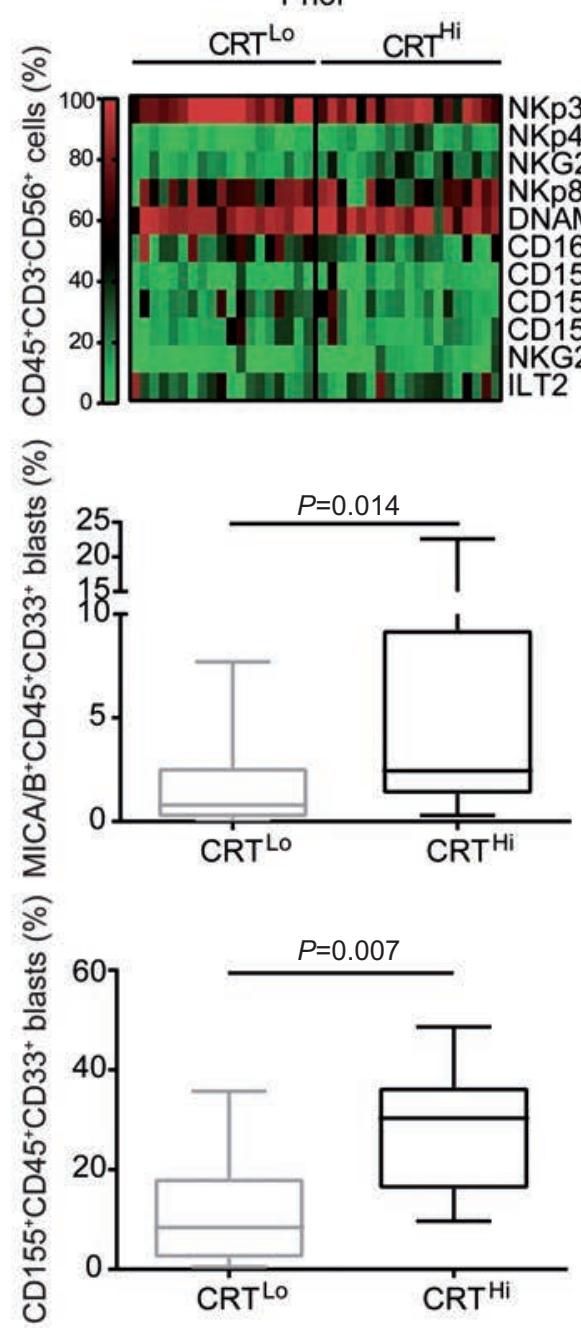

B

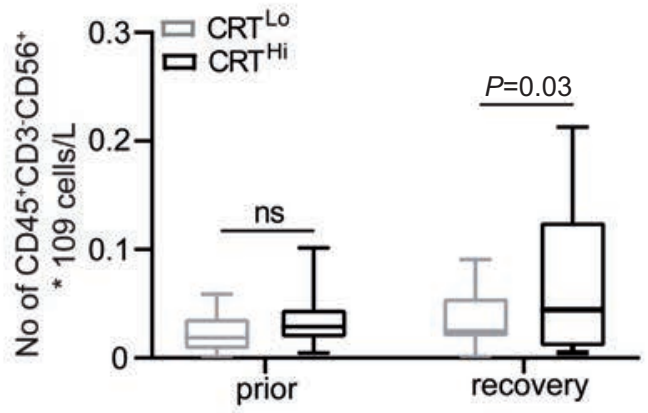

Recovery
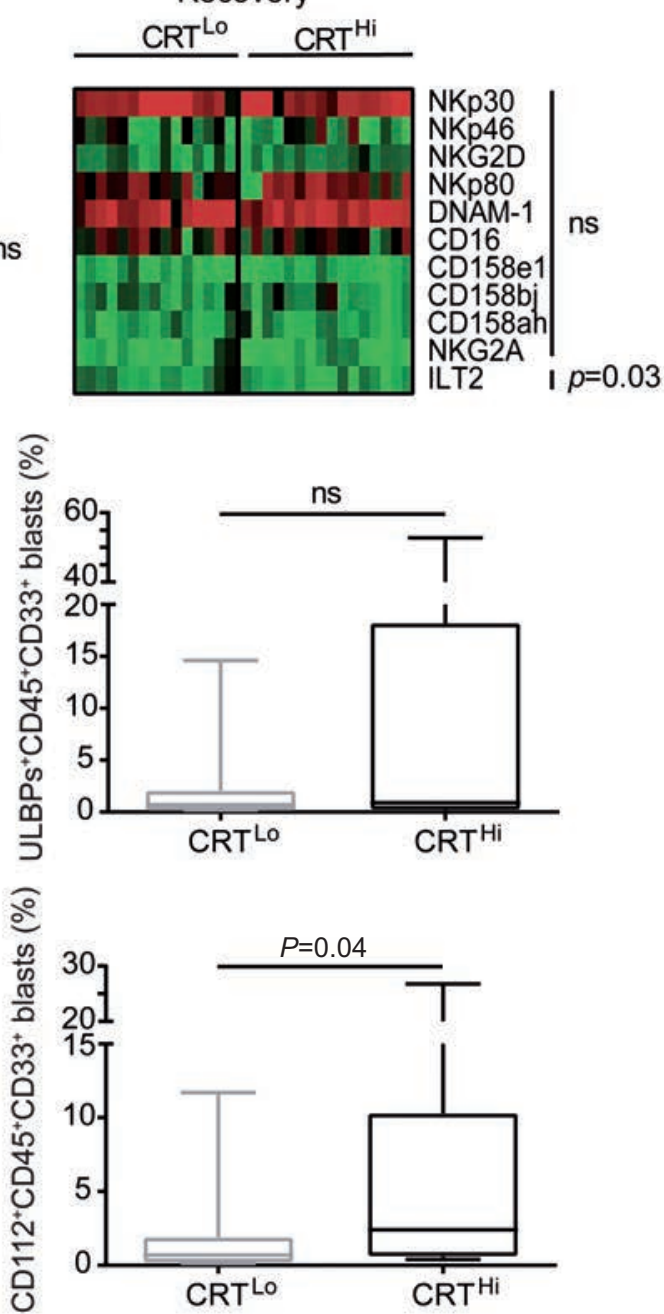

Figure 1. The impact of ecto-CRT on natural killer (NK) cells and the levels of NK-cell ligands present on acute myeloid leukemia blasts. (A) The percentage and (B) absolute numbers of circulating $\mathrm{CD} 45^{+} \mathrm{CD} 3 \mathrm{CD}^{2} 6^{+} \mathrm{NK}$ cells in $\mathrm{CRT}^{\mathrm{Hi}}$ versus $\mathrm{CRT}^{\mathrm{Lo}}$ acute myeloid leukemia (AML) patients before the induction chemotherapy (Prior, $\mathrm{n}=45$ ) and at re-establishment of normal hematopoiesis (recovery, $\mathrm{n}=37$ ) determined by flow cytometry. Boxplots: lower quartile, median, upper quartile; whiskers, minimum, maximum; ns: not significant. (C) The frequency of CD45+CD3CD56 ${ }^{+}$NK cells staining positively for different NK cell receptors (namely NKp30, NKp46, NKG2D, NKp80, DNAM-1, CD16, CD158e1, CD158bj, CD158ah, NKG2A and ILT2) in CRT ${ }^{\text {Hi }}$ and CRT ${ }^{\text {Lo }}$ AML patients before the induction chemotherapy (prior, $\mathrm{n}=38$ ) and at re-establishment of normal hematopoiesis (recovery, $n=31$ ) determined by flow cytometry. ns: not significant. (D) The percentage of $C D 45^{+} C D 33^{+}$blasts staining positively for NK cell ligands (MICA/B, ULBP, CD155 and CD112) in CRT ${ }^{\text {Hi }}$ versus CRT ${ }^{\text {Lo }} \mathrm{AML}$ patients prior to the induction chemotherapy ( $\mathrm{n}=21$ ) determined by flow cytometry. Boxplots: lower quartile, median, upper quartile; whiskers, minimum, maximum; ns: not significant. CRT: calreticulin. 
to efficiently kill K562 cells (Figure 2D), CRT ${ }^{\text {Hi }}$ patients in remission possessed $\mathrm{NK}$ cells with superior cytotoxic functions compared to their CRT ${ }^{\mathrm{Lo}}$ counterparts (Figure $2 \mathrm{E})$. These data are consistent with the results reported above (Figure 2A-B).

\section{Surface-exposed CRT influences NK-cell effector functions indirectly, by affecting the phenotype of CD11 $c^{+}$CD14 ${ }^{\text {high }}$ cells}

To further evaluate the impact of surface-exposed CRT on NK cells and the mechanisms underlying its NK cellstimulatory effects, we performed a set of in vitro experi- ments with recombinant CRT (rCRT). Pre-incubation of purified NK cells with rCRT did not affect the capacity of NK cells to release cytotoxic granules containing perforin 1 (PRF1) or secrete IFN- $\gamma$ in response to either nonspecific stimulation with PMA and ionomycin or exposure to K562 cells (Figure 3A and Online Supplementary Figure 2A). Conversely, adding rCRT to whole PBMCs led to significant increase in the percentage of $\mathrm{CD}_{4} 5^{+} \mathrm{CD}^{-} \mathrm{CD} 56^{+} \mathrm{NK}$ cells degranulating in response to PMA plus ionomycin or exposure to K562 cells (Figure 3B), with no effects on IFN$\gamma$ secretion (Online Supplementary Figure S2B). We confirmed these results with NK-cell cytotoxicity assays, as
A

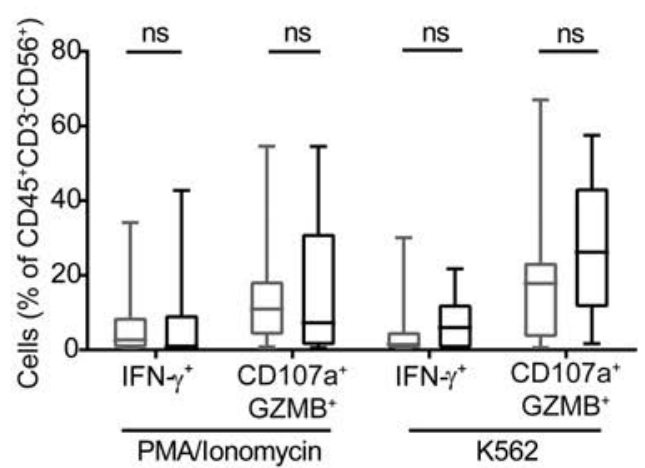

B

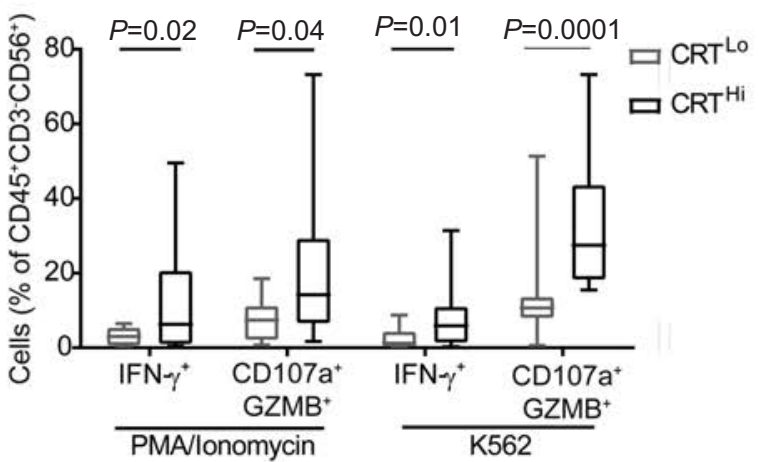

C

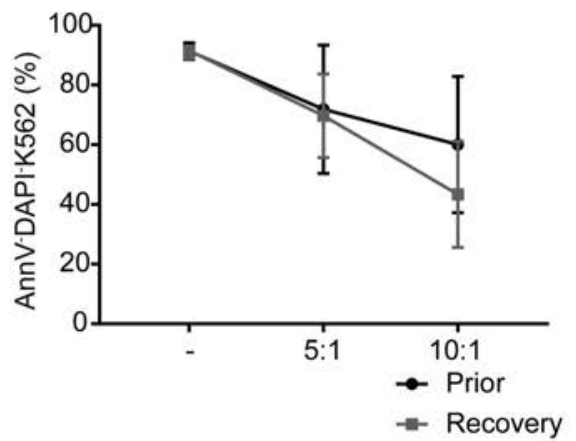

D
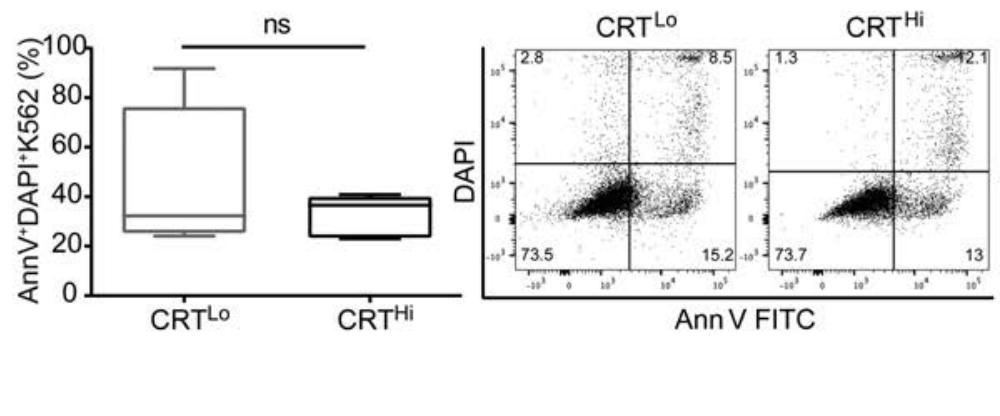

E

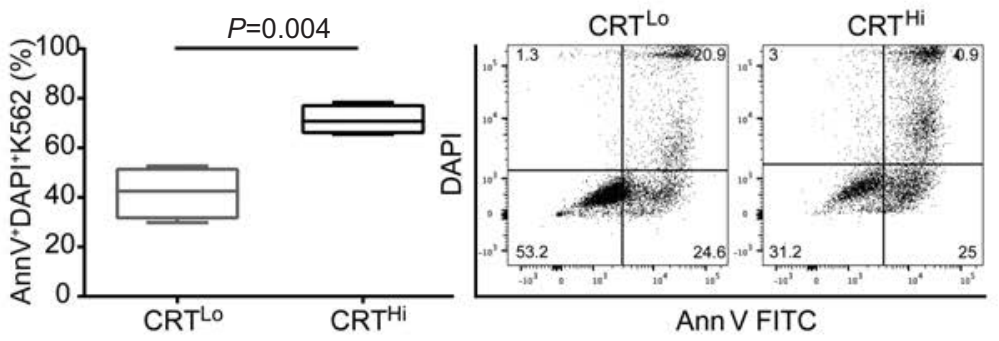

Figure 2. The impact of ecto-CRT on the activation and cytotoxic potential of natural killer cells in acute myeloid leukemia patients. (A, B) The percentage of IFN- $\gamma$ and degranulating $\left(\mathrm{CD} 107 \mathrm{a}^{+} / \mathrm{GZMB}^{+}\right) \mathrm{CD}^{2} 5^{+} \mathrm{CD}^{-} \mathrm{CD}^{-} 6^{+}$natural killer (NK) cells upon PMA + lonomycin or K562 cell line stimulation in $17 \mathrm{CRT}^{\mathrm{L}}$ and $18 \mathrm{CRT}^{\mathrm{Hi}}$ acute myeloid leukemia (AML) patients prior to the induction chemotherapy (A) or in $12 \mathrm{CRT}^{\mathrm{Lo}}$ and $12 \mathrm{CRT}^{\mathrm{Hi}} \mathrm{AML}$ patiens after the restoration of normal hematopoiesis (B). Patient samples were analyzed by flow cytometry. Box plots: lower quartile, median, upper quartile; whiskers, minimum, maximum; ns: not significant. (C) Cytotoxic potential of NK cells isolated from AML patients before the initiation of chemotherapy (Prior, $n=10$ ) versus upon the restoration of normal hematopoiesis (Recovery, $n=10)$. Purified NK cells were tested for their ability to kill target K562 cell line at two different effector:target cell ratios $(5: 1$ and $10: 1)$ and the viability of K562 cells was determined by flow cytometry after 4 hours $(\mathrm{h})$. (D, E) Cytotoxic potential of NK cells isolated from five CRT ${ }^{\mathrm{Hi}}$ and $5 \mathrm{CRT}^{\mathrm{LO}} \mathrm{AML}$ patients before the initiation of chemotherapy (D) or upon the restoration of normal hematopoiesis (E). Purified NK cells were tested for their ability to kill target K562 cell line at effector:target cell ratio $5: 1$ and the percentage of dead $\left(\mathrm{AnnV}^{+} \mathrm{DAPI} \mathrm{I}^{+}\right) \mathrm{K} 562$ cells was determined by flow cytometry after $4 \mathrm{~h}$. The representative dot plots of NK cell cytotoxicity assay showing the viability of target $\mathrm{K} 562$ cells in $\mathrm{CRT}^{\mathrm{Hi}}$ versus $\mathrm{CRT}^{\mathrm{LO}} \mathrm{AML}$ patients before the initiation of chemotherapy (D) or upon the restoration of normal hematopoiesis (E) are shown. Box plots: lower quartile, median, upper quartile; whiskers, minimum, maximum; ns: not significant. CRT: calreticulin. 
NK cells isolated from PBMCs pre-incubated with rCRT were able to kill an increased amount of K562 cells compared to NK cells isolated from control PBMC (Figure 3B). These results suggest that CRT stimulate NK cells indirectly, via mechanisms that involve other cellular components of the PBMC mixture.

Previous in vitro studies support a role for APCs, mainly DCs, in NK-cell activation. ${ }^{23}$ We therefore decided to focus on the phenotype of APCs exposed to rCRT. We found that incubating PBMCs from healthy donors (HD) with rCRT induced the upregulation of the chemotaxisassociated receptor C-C motif chemokine receptor 7 (CCR7) and the maturation-associated molecules CD86 and HLA-DR on CD11 $\mathrm{c}^{+} \mathrm{CD} 14^{\text {high }}$ cells and increased the frequency of $\mathrm{CD} 11 \mathrm{c}^{+} \mathrm{CD} 14^{\text {high }}$ expressing interleukin 15 receptor subunit alpha (IL15RA, best known as IL-15R $\alpha$ ) (Figure $3 \mathrm{C}$ ), which is crucial for the activatory trans-presentation of IL-15 to NK cells. ${ }^{24}$ Inspired by these data, we investigated the relationship between CRT exposed on malignant blasts and the phenotype of APCs in AML patients in remission. We found that CRT ${ }^{\mathrm{Hi}}$ patients harbor a significantly higher percentage of $\mathrm{CD} 11 \mathrm{c}^{+} \mathrm{CD} 14^{\text {high }}$ cells expressing CCR7 and IL-15R $\alpha$ compared to their $\mathrm{CRT}^{\text {Lo }}$ counterparts (Figure $3 \mathrm{D}$ ), suggesting that these cells have an increased capacity to migrate to secondary lymphoid organs, where they can efficiently activate NK cells. In vitro assays suggested a prominent role for human myeloid over plasmocytoid DCs in NK-cell activation upon exposure to rCRT (Online Supplementary Figure S3A). Of note, also mouse PBMCs or bone marrow-derived DCs exposed to rCRT upregulated activation markers including CD54, CD86, and MHC class II molecules, and secreted increased amounts of IL-12 (Online Supplementary Figure S3B-D).

We have previously shown that the PMBCs of $\mathrm{CRT}^{\mathrm{Hi}}$ AML patients who are in complete remission and have
A

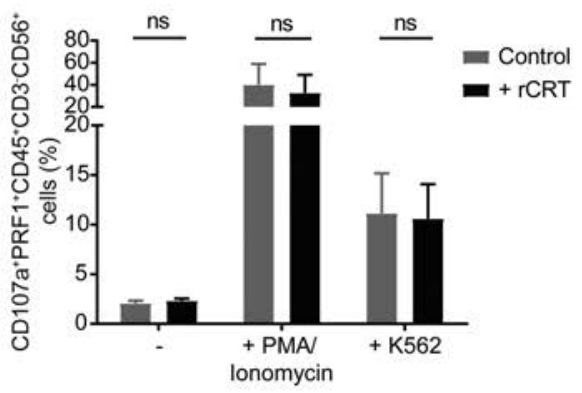

B
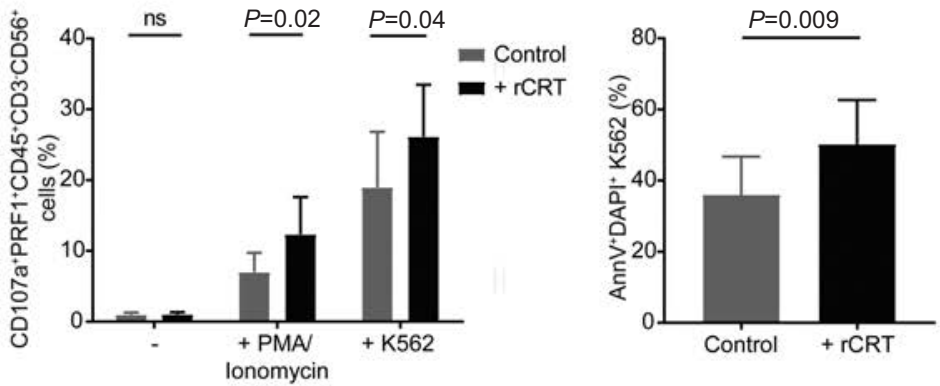

C
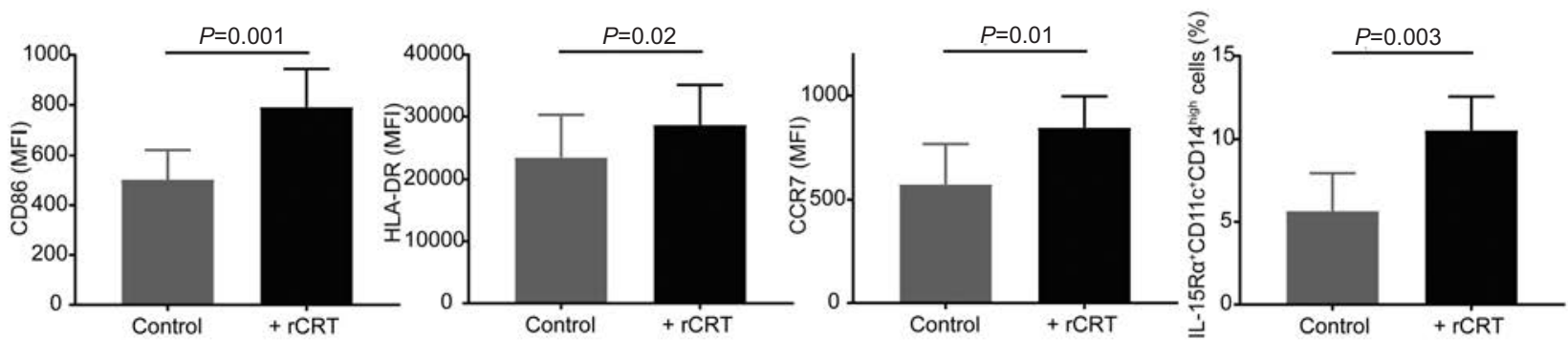

D
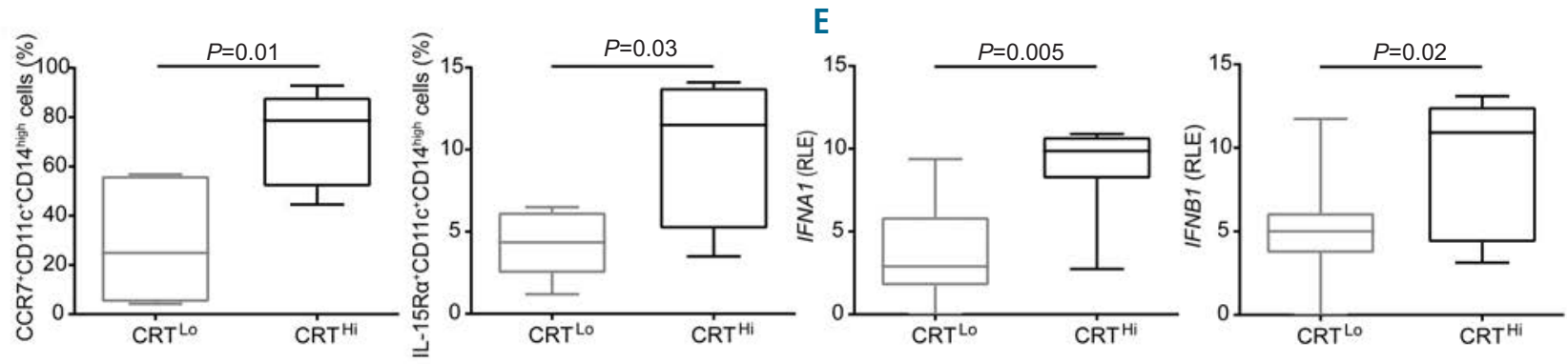

Figure 3. The mechanism of natural killer cell-stimulatory effects of calreticulin and its impact on $\mathrm{CD} 11 \mathrm{c}^{+} \mathrm{CD} 14^{\text {high }}$ cell phenotype. (A, B) The effect of recombinant human calreticulin (rCRT, Sino Biological Inc.) on effector functions of natural killer (NK) cells isolated from healthy donors (HDs) ( $n=8)$ or NK cells in HD peripheral blood mononuclear cells (PBMC) mixture $(n=8)$. Purified NK cells $(A)$ or whole PBMC (B) were pre-incubated with $5 \mu \mathrm{g} / \mathrm{mL}$ of rCRT overnight and subsequently stim-

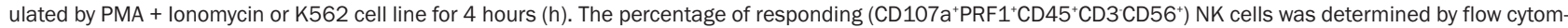
etry. Alternatively, NK cells were purified from rCRT-pre-incubated PBMC and their capacity to kill K562 cell line was tested in cytotoxicity assay. The percentage of dead $\left(\mathrm{AnnV}^{+} \mathrm{DAPI}^{+}\right) \mathrm{K} 562$ cells was determined by flow cytometry after $4 \mathrm{~h}$ (B). NK cells/PBMCs without rCRT and unstimulated NK cells/PBMC were used as a negative controls; ns: not significant. (C) The expression of maturation-associated molecules (CD86 and HLA-DR) and CCR7 on CD11c ${ }^{+} C D 14^{\text {high }}$ cells in HD PBMCs ( $n=8$ ) incubated with rCRT ( $5 \mu \mathrm{g} / \mathrm{mL}$ ) overnight versus control PBMCs without rCRT as determined by flow cytometry. The expression of individual markers is shown as mean fluorescence intensity (MFI). Flow cytometry was also used for the detection of IL-15R $\alpha^{+} C D 11 C^{+} C D 14^{\text {high }}$ cells in rCRT-pre-incubated versus control PBMCs. (D) The frequency of $\mathrm{CCR} 7+$ and IL-15R $\alpha^{+} \mathrm{CD} 11 \mathrm{C}^{+} \mathrm{CD} 14^{\text {high }}$ cells in $\mathrm{CRT}^{\mathrm{Hi}}$ versus $\mathrm{CRT} \mathrm{L}^{\mathrm{L}} \mathrm{AML}$ patients upon the restoration of normal hematopoiesis ( $\mathrm{n}=16$ ) determined by flow cytometry. Boxplots: lower quartile, median, upper quartile; whiskers, minimum, maximum. (E) Quantitative RT-PCR-assisted quantification of IFNA1 and IFNB1 expression levels in PBMCs from $20 \mathrm{CRT}^{\mathrm{Hi}}$ versus $21 \mathrm{CRT}^{\mathrm{L}}{ }^{\circ}$ acute myeloid leukemia (AML) patients at recovery of normal hematopoiesis. Boxplots: lower quartile, median, upper quartile; whiskers, minimum, maximum. 
recovered normal, non-malignant hematopoiesis exhibit a remarkable upregulation of genes linked to $T_{H} 1$ polarization, T-cell activation and cytotoxic immune responses. ${ }^{10}$ To confirm and extend these findings, we assessed the expression levels of 46 genes linked to immune function, with particular focus on NK-cell activity, in the PBMCs of 37 AML patients in remission (Online Supplementary Table S3). We identified five genes that were differentially expressed in $\mathrm{CRT}^{\mathrm{Hi}}$ versus $\mathrm{CRT}^{\mathrm{Lo}}$ patients, namely, IFNA1, IFNB1, CD3E, CD8A and CD28 (Figure $3 \mathrm{E}$ and Online Supplementary Figure $S 4 A$ ). Importantly, type I IFN including the products of IFNA1 and IFNB1 are also involved in the capacity of DCs to enhance NK-cell effector functions (23).

Taken together, our results suggest that CRT exposure on the surface of malignant blasts stimulates NK-cell effector functions indirectly, by altering the migratory capacity, surface phenotype, and secretory profile of CD11 $c^{+} \mathrm{CD} 14^{\text {high }}$ APCs.
CRT exposure is associated with increased NK- and T-cell responses in mice

To examine the impact of surface-exposed CRT on anticancer immunity in vivo, we generated subcutaneous tumors in B6 mice with mouse wild-type (WT) AML C1498 cells (C1498.WT) or C1498 cells constitutively exposing CRT on the plasma membrane (C1498.CRT), and monitored disease progression (data not shown) and immune responses. T-cell response was analyzed both in the tumor and spleen (19 days after tumor cell injection) and NK-cell response only in spleen (three days after tumor cell injection) (Figure 4A). Importantly, developing C1498.CRT tumors resulted in an enrichment of activated CD107 $\mathrm{a}^{+} \mathrm{NK}$ cells (defined as $\mathrm{CD} 45^{+} \mathrm{CD}^{-} \mathrm{NK} 1.1^{+}$cells) in the spleen, and enhanced the capacity of NK cells to respond to PMA plus ionomycin stimulation (Figure 4B). In addition, we observed that C1498.CRT tumors are infiltrated by $\mathrm{CD}^{+}$and $\mathrm{CD}^{+} \mathrm{T}$ cells with improved effector functions in response to non-specific stimulation with

A

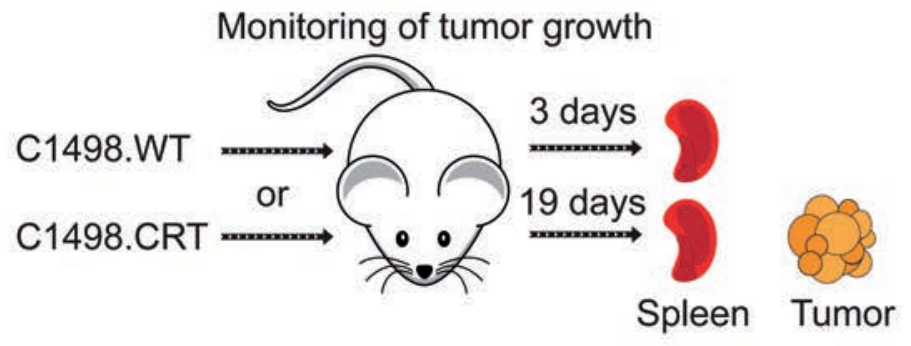

\section{Cytometric analysis}

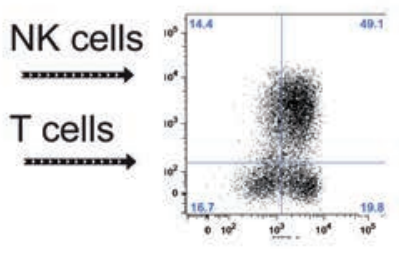

B

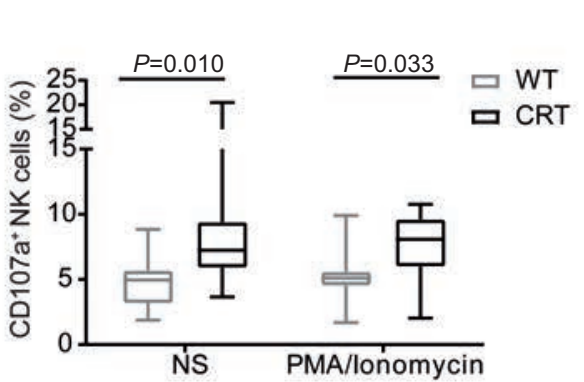

C

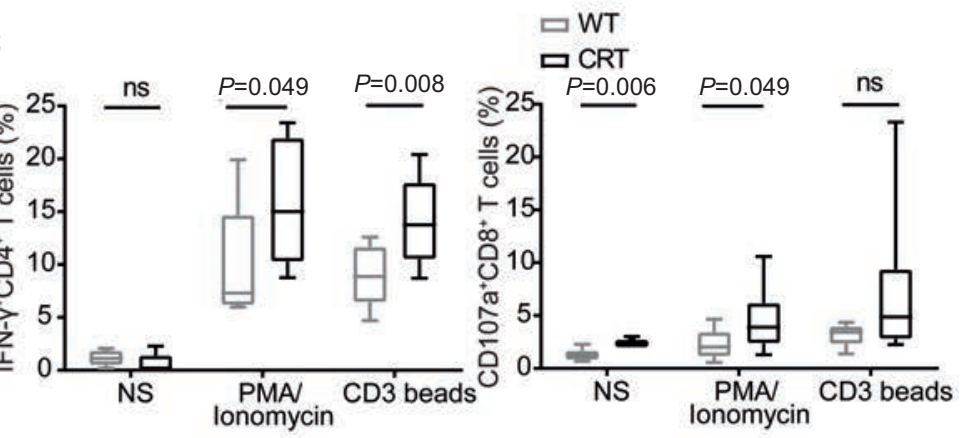

D

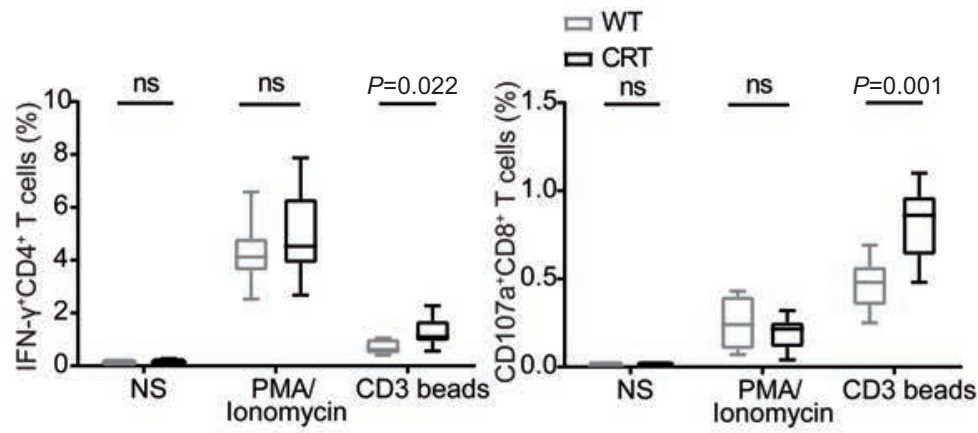

Figure 4. The role of calreticulin in natural killer-cell- and T-cell-based immune response in vivo in mice. (A) Schematic representation showing the process of C1498.WT/CRT tumor generation and monitoring the immune responses. To generate tumors in vivo, $1 \times 10^{6}$ C1498.WT or C1498.CRT cells were inoculated sub cutaneoulsy into the lower right flank of B6 mice on day 0 (D0). Tumor size was measured every two days by standard laboratory caliper. Mice were sacrificed on D3 or D19 and spleen and tumors were harvested for analysis of functional status of natural killer (NK) cells (spleen on D3) and T cells (both spleen and tumors on D19) by flow cytometry. The experiment was performed three times. (B) The frequency of CD107a+ $\mathrm{NK}$ cells (defined as $\mathrm{CD} 45^{+} \mathrm{CD} 3^{-} \mathrm{NK} 1.1^{+}$cells) in spleen harvested from mice injected with C1498.CRT versus C1498.WT without further in vitro stimulation or upon stimulation with PMA + Ionomycin determined by flow cytometry. Box plots: lower quartile, median, upper quartile; whiskers, minimum, maximum. (C, D) The frequency of activated IFN- $\gamma^{+} \mathrm{CD} 4^{+} \mathrm{T}$ cells and CD107a $\mathrm{a}^{+} \mathrm{CD} 8^{+} \mathrm{T}$ cells upon in vitro PMA + lonomycin or anti-CD3 bead stimulation in C1498.CRT versus C1498.WT tumors (C) or spleen (D) determined by flow cytometry. Unstimulated cells were used as a controls. Box plots: lower quartile, median, upper quartile; whiskers, minimum, maximum; ns: not significant. WT: wild-type. 
PMA plus ionomycin and/or anti-CD3 beads (Figure 4C). Similarly, splenocytes isolated from C1498.CRT-bearing mice contained $\mathrm{CD}^{+}$and $\mathrm{CD}^{+} \mathrm{T}$ cells that were more responsive to stimulation than their counterparts from C1498.WT-bearing mice (Figure 4D).

In line with this notion, PBMCs from $\mathrm{CRT}^{\mathrm{Hi}} \mathrm{AML}$ patients in complete remission contained significantly higher frequencies of both $\mathrm{CD}^{+}$and $\mathrm{CD}^{+} \mathrm{T}$ cells responding by IFN- $\gamma$ secretion to PMA plus ionomycin (Online Supplementary Figure S4B-C), with a slightly subsignificant trend towards increased numbers of $\mathrm{CD} 107 \mathrm{a}^{+} \mathrm{GZMB} \mathrm{B}^{+} \mathrm{CD} 8^{+} \mathrm{T}$ cells (Online Supplementary Figure S4D), compared with their CRT ${ }^{\text {Lo }}$ counterparts, comforting previously published data from our group. ${ }^{10}$ Quantification of several cytokines essential for NK-cell homeostasis and functions (IL-21, IL-15, IFN- $\gamma$ and IFN- $\alpha 2$ ) and for hematopoietic stem cell (HSC) differentiation (IL-3 and IL-7) in the sera of AML patients in remission also revealed higher IFN-y levels in CRT ${ }^{\mathrm{Hi}}$ versus CRT $^{\text {Lo }}$ patients (Online Supplementary Figure S4E).

\section{CRT exposure on malignant blasts and the frequency of NKG2D+ cells correlate with RFS in AML patients}

To evaluate the prognostic impact of CRT exposure on malignant blasts and verify our previous results on a larger subgroup of our patients, ${ }^{10}$ we investigated RFS upon stratifying AML patients based on the median percentage of DAPI- blasts staining positively for surface CRT. In line with our previous observations, ${ }^{10} \mathrm{CRT}^{\mathrm{Hi}}$ patients exhibited a significantly improved RFS compared with CRT ${ }^{\text {Io }}$ patients (median: $>60$ vs. 14 months, $P=0.027$ ) (Figure $5 \mathrm{~A})$. Using a similar cutoff approach based on the median value, we also examined whether the mRNA levels of $K L R K 1$, encoding the key NK-cell activating receptor NKG2D, would convey prognostic information in AML patients. We found that patients expressing high levels of KLRK1 (KLRK $1^{\text {Hi }}$ ) had a significantly lower risk of relapse compared to their KLRK $1^{\text {Lo }}$ counterparts (median: 39 vs. 10 months, $P=0.039$ ) (Figure $5 \mathrm{~B}$ ). We validated these findings at the protein level by stratifying a larger group of patients based on the median frequency of $\mathrm{CD} 45^{+} \mathrm{CD} 3$ $\mathrm{CD}^{+} 6^{+} \mathrm{NKG} 2 \mathrm{D}^{+} \mathrm{NK}$ cells. Patients with a high frequency of NK cells expressing NKG2D (NKG2D ${ }^{\mathrm{Hi}}$ ) exhibited significantly improved RFS, compared with their NKG2D ${ }^{10}$ counterparts (median: $>35$ vs. 24 months, $P=0.035$ ) (Figure 5C). However, neither univariate nor multivariate Cox proportional hazard analysis confirmed these findings, potentially reflecting a limited follow-up of this prospectively collected patient cohort, or other confounding factors including disease subtype and inter-individual heterogeneity (Table 2-3). Since both CRT exposure on malignant blasts and NKG2D levels influenced RFS in our cohort of AML patients, we evaluated the combined prognostic value of ecto-CRT ${ }^{+}$blasts and the KLRK1 mRNA levels or $\mathrm{CD}_{4} 5^{+} \mathrm{CD} 3^{-} \mathrm{CD} 56^{+} \mathrm{NKG} 2 \mathrm{D}^{+} \mathrm{NK}$-cell frequency by stratifying the cohort in three groups: $\mathrm{CRT}^{\mathrm{Hi}} / K L R K 11^{\mathrm{Hi}}$ or $\mathrm{CRT}^{\mathrm{Hi}} / \mathrm{NKG} 2 \mathrm{D}^{\mathrm{Hi}}$ patients, $\mathrm{CRT}^{\mathrm{Lo}} / K L R K 1^{\mathrm{Lo}}$ or $\mathrm{CRT}^{\mathrm{Lo}} / \mathrm{NKG} 2 \mathrm{D}^{\mathrm{Lo}}$ patients and patients in which the percentage of $\mathrm{CRT}^{+}$blasts was discordant with the KLRK1 mRNA levels or the frequency of $\mathrm{CD} 45^{+} \mathrm{CD} 3{ }^{-} \mathrm{CD} 56^{+} \mathrm{NKG} 2 \mathrm{D}^{+} \mathrm{NK}$ cells $\left(\mathrm{CRT} / K L R K 1^{\text {Mix }}\right.$ or CRT/NKG2D $\left.{ }^{\mathrm{Mix}}\right)$. We found that $\mathrm{CRT}^{\mathrm{Hi}} / K L R K 1^{\mathrm{Hi}}$ or CRT $T^{\mathrm{Hi}} / \mathrm{NKG} 2 \mathrm{D}_{\mathrm{Hi}}^{\mathrm{Hi}}$ patients had superior RFS as compared with their CRT $T^{\text {Lo }} / K L R K 1^{\text {Lo }}$ or $C R T^{\text {Lo }} / \mathrm{NKG}^{2} \mathrm{D}^{\mathrm{Lo}}$ counterparts $\left(\mathrm{CR} T^{\mathrm{Hi}} / K L R K 1^{\mathrm{Hi}}\right.$ vs. $\mathrm{CRT}^{\mathrm{Lo}} / K L R K 1^{\mathrm{Lo}}, \quad P=0.050$;
$\mathrm{CRT}^{\mathrm{Hi}} / \mathrm{NKG}_{2} \mathrm{D}^{\mathrm{Hi}}$ vs. $\mathrm{CRT}^{\mathrm{Lo}} / \mathrm{NKG}^{\mathrm{D}} \mathrm{D}^{\mathrm{Lo}}, \quad P=0.037$ ) (Figure 5D-E).

\section{Discussion}

CRT exposure on cancer cells conveys robust prognostic information in patients with a variety of malignancies, generally reflecting the activation of clinically-relevant tumor-targeting immune responses. ${ }^{13}$ Previous work from our group demonstrated that the presence of CRT on the surface of malignant blasts from AML patients correlates not only with an increased frequency of effector memory $\mathrm{CD} 4^{+}$and $\mathrm{CD} 8^{+} \mathrm{T}$ cells but also with an increased proportion of circulating NK cells, suggesting that CRT exposure is linked to both adaptive and innate immunity. ${ }^{10}$ Inspired by accumulating evidence on the key role of NK cells in natural and therapy-driven immunosurveillance, ${ }^{25-29}$ we decided to extend these initial observations and characterize the link between surface-exposed CRT and NK-cell activity in AML patients. Indeed, NK cells from patients with high CRT exposure on malignant blasts exhibited improved secretory and cytotoxic effector functions (Figure 2B and E).

As we excluded the possibility that CRT would mediate direct immunostimulatory effects on NK cells (Figure 3A and Online Supplementary Figure S2A), we thought that CRT exposure would be linked to increased levels of NKALs on the surface of malignant blasts, because both these processes have been linked to intracellular ER stress signaling. ${ }^{30}$ Indeed, the percentage of $\mathrm{CD} 45^{+} \mathrm{CD} 33^{+}$malignant blasts staining positively for ecto-CRT ${ }^{+}$correlated with the frequency of blasts staining positively for various NKALs (Figure 1D). However, we were unable to document any correlation between the NKAL expression levels and mRNA abundance of genes involved in the ER stress response (which we and others previously demonstrated to constitutively occur in AML blasts independent of therapy) ${ }^{10,12}$ (Online Supplementary Figure S1C). These findings suggest that NKALs and CRT are exposed on the surface of AML blasts via mechanistically distinct stress response pathways. Replication stress and the consequent DNA damage response stand out as a promising candidate for NKAL exposure in this setting. ${ }^{30}$

We also found that NK-cell activation by CRT involves a population of $\mathrm{CD} 11 \mathrm{c}^{+} \mathrm{CD} 14^{\text {high }}$ cells that, upon exposure to CRT, express maturation markers (CD86 and HLA-DR), acquires improved migratory capacity as a consequence of CCR7 expression, and delivers stimulatory signals to NK cells via IL-15R $\alpha /$ IL-15 trans-presentation ${ }^{24}$ and type I IFN. Consistent observations in peripheral blood of HDs and AML patients, suggest that $\mathrm{CD} 11 \mathrm{c}^{+} \mathrm{CD} 14^{\text {high }}$ cells exposed to CRT have a superior capacity to migrate to secondary lymphoid organs where they can efficiently activate NK cells (Figure 3C-E). Thus, surface-exposed CRT appears to trigger the phenotypic and functional maturation of $\mathrm{CD} 11 \mathrm{c}^{+} \mathrm{CD} 14^{\text {high }}$ cells leading to (i) cell contact-dependent NK-cell activation via trans-presented IL-15, as well as (ii) cell contact-independent NK-cell activation via type I IFNs. Importantly, type I IFN signaling in DCs results not only in a superior ability to drive antigen-specific T-cell priming, ${ }^{31}$ but also in IL-15 production, ${ }^{32}$ potentially supporting a robust adaptive and innate immune response of therapeutic relevance. Our findings and elegant preclinical data from Chen and colleagues ${ }^{10,33}$ lend robust support to 
A
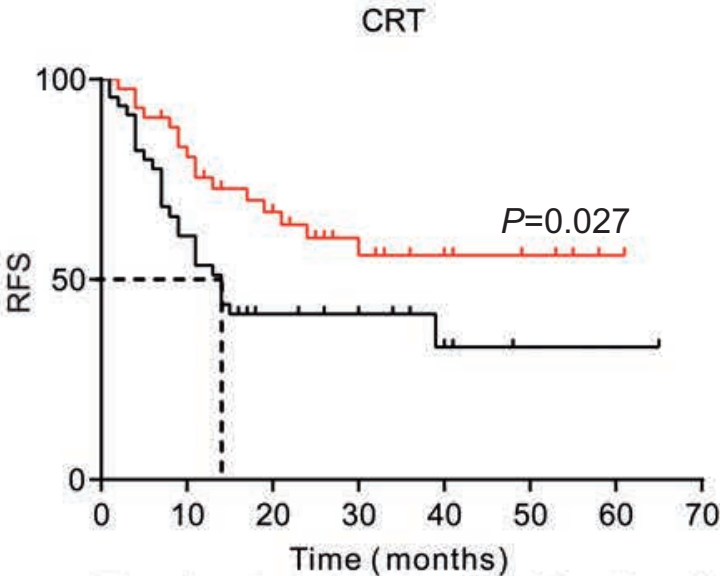

$\begin{array}{lllllll}\text { Time (months) } & 0 & 10 & 20 & 30 & 40 & 60\end{array}$

$\begin{array}{lllllll}\text { CRT }^{\text {HI }} & 42 & 33 & 22 & 14 & 8 & 2 \\ \text { CRTLO }^{\text {CR }} & 45 & 27 & 14 & 9 & 4 & 2\end{array}$

C

NKG2D

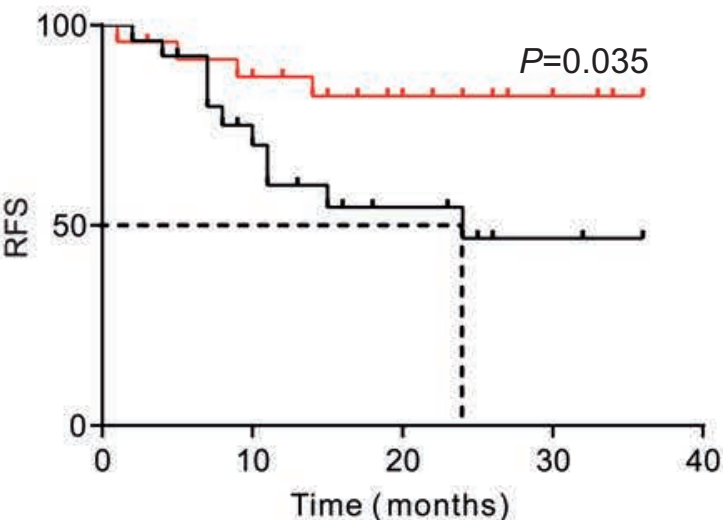

$\begin{array}{llllll}\text { Time (months) } & 0 & 10 & 20 & 30 & 35\end{array}$

$\begin{array}{llllll}\text { NKG2D } & 24 & 20 & 12 & 7 & 3\end{array}$

$\begin{array}{llllll}\text { NKG2DLO } & 26 & 15 & 9 & 5 & 1\end{array}$

E

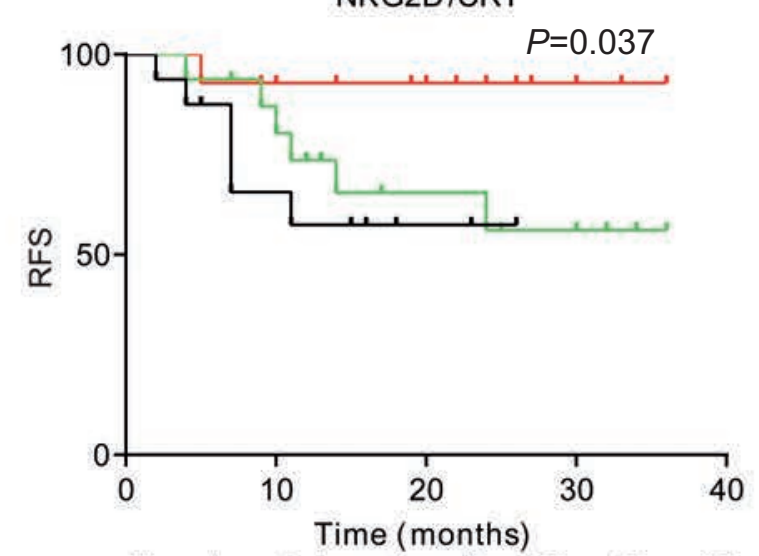

$\begin{array}{llllll}\text { Time (months) } & 0 & 10 & 20 & 30 & 35\end{array}$

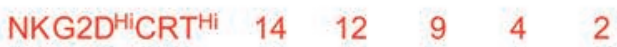

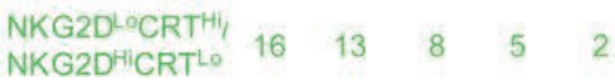

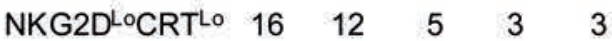

B

KLRK1

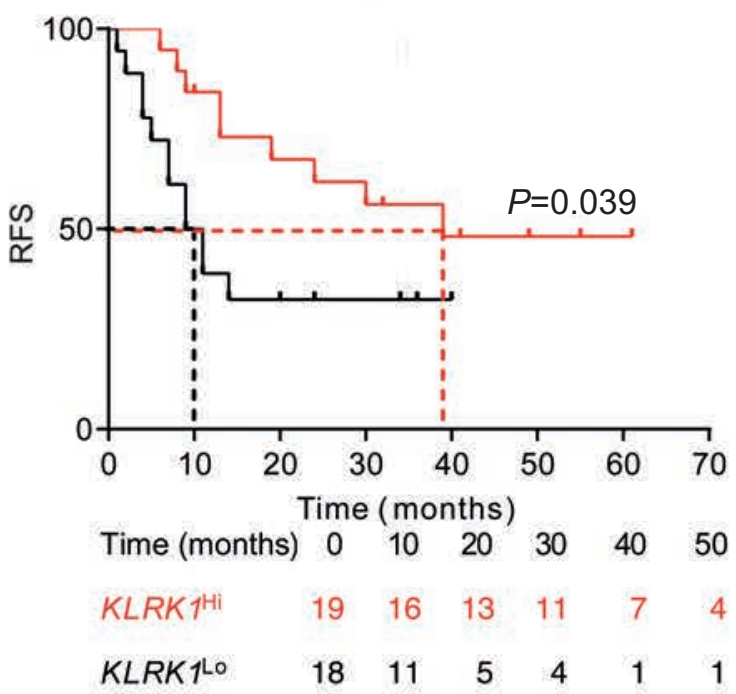

D

\section{KLRK1/CRT}

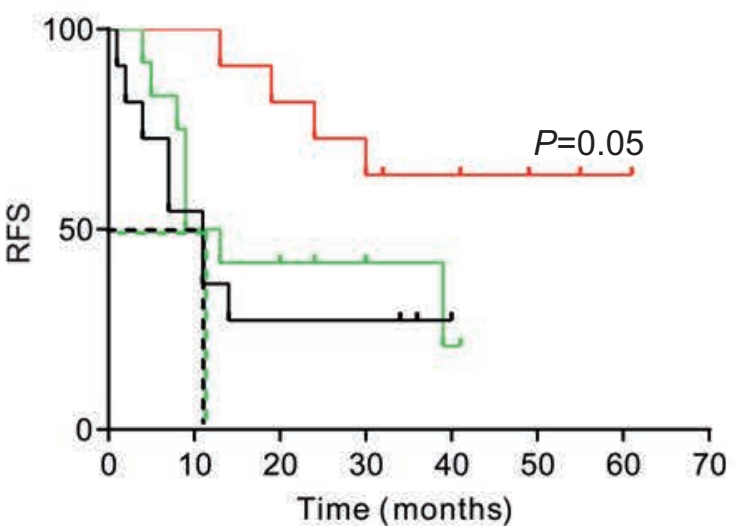

$\begin{array}{lllllll}\text { Time (months) } & 0 & 10 & 20 & 30 & 40 & 50\end{array}$

$\begin{array}{lllllll}\text { KLRK }^{\mathrm{Hi}} \mathrm{CR} \mathrm{T}^{\mathrm{Hi}} & 11 & 11 & 10 & 8 & 6 & 4\end{array}$

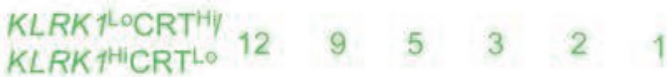

$\begin{array}{lllllll}\text { KLRK }^{\text {K }} \text { LOCRT }^{\text {Lo }} & 11 & 8 & 4 & 4 & 1 & 1\end{array}$

Figure 5. Prognostic value of ecto-calreticulin and activating natural killer cell receptor NKG2D in acute myeloid leukemia patients. (A, B, C) Relapse-free survival (RFS) of acute myeloid leukemia (AML) patients stratified in two groups based on median percentage of circulating ecto-CRT ${ }^{+}$blasts $(n=87)(A)$, on median mRNA levels of KLRK1 $(n=37)(B)$ or the frequency of $C D 45^{+} C D 3^{-}{ }^{-}{ }^{-} 56^{+}$ natural killer (NK) cells staining positively for NKG2D $(n=50)(C)$ analyzed upon complete remission. Survival curves were estimated by the Kaplan-Meier method and differences between groups were evaluated using log-rank test. Number of patients at risk is reported. (D, E) RFS of AML patients upon stratification based on median percentage of circulating ecto-CRT ${ }^{+}$blasts along with median KLRK1 mRNA levels (D) or NKG2D+CD45+CD3CD56 ${ }^{+} \mathrm{NK}$ cell frequency

(E). Survival curves were estimated by the Kaplan-Meier method, and differences between groups were evaluated using log-rank test. Number of patients at risk is reported. CRT: calreticulin. 
Table 2. Univariate Cox proportional hazard analysis.

\begin{tabular}{lcc} 
Variable & HR $(95 \%$ Cl) & RFS \\
Age & $1.02(0.99-1.04)$ & 0.19 \\
Sex & $0.79(0.44-1.43)$ & 0.45 \\
\hline Peripheral blast counts & $1.00(0.99-1.01)$ & 0.26 \\
HSCT & $0.76(0.40-1.44)$ & 0.40 \\
\hline Ecto-CRT ${ }^{+}$blasts (\%) & $0.99(0.98-1.00)$ & 0.22 \\
KLRK1 expression & $0.80(0.53-1.19)$ & 0.27 \\
\hline NKG2D+ NK cells (\%) & $0.96(0.92-1.01)$ & 0.13 \\
\hline
\end{tabular}

$\mathrm{CI}, 95 \%$ confidence interval; $\mathrm{HR}$, hazard ratio; * $\mathrm{p}<0.05$; RFS, relapse-free survival.
Table 3. Multivariate Cox proportional hazard analysis.

\begin{tabular}{lcc} 
Variable & HR $(95 \%$ Cl) & RFS \\
Age & $1.07(1.01-1.13)$ & P \\
Sex & $1.34(0.50-3.60)$ & $0.007^{*}$ \\
\hline Peripheral blast counts & $1.00(0.98-1.02)$ & 0.71 \\
HSCT & $0.62(0.21-1.83)$ & 0.39 \\
\hline Ecto-CRT' blasts (\%) & $0.98(0.96-1.00)$ & 0.10 \\
KLRK1 expression & $0.69(0.44-1.07)$ & 0.10 \\
\hline NKG2D+ NK cells (\%) & $0.95(0.90-1.01)$ & 0.11 \\
\hline
\end{tabular}

$\mathrm{CI}, 95 \%$ confidence interval; $\mathrm{HR}$, hazard ratio; ${ }^{*} \mathrm{p}<0.05$; RFS, relapse-free survival. this possibility. Indeed, in vivo application of C1498 AML cells engineered to constitutively expose CRT on their surface elicited an accumulation of highly functional NK cells and $\mathrm{CD}^{+}$and $\mathrm{CD}^{+} \mathrm{T}$ cells in mouse tumors and/or spleen (Figure 4B-D).

Finally, both CRT exposure on malignant blasts and NK cell-related marker NKG2D were associated with improved RFS amongst AML patients (Figure 5A-C), corroborating previously published data. ${ }^{10,34}$ Combinatorial assessment of the prognostic value of these parameters identified significantly prolonged RFS in KLRK $1{ }^{\mathrm{Hi}} \mathrm{CRT}{ }^{\mathrm{Hi}}$ and NKG2D ${ }^{\mathrm{Hi}} \mathrm{CRT} \mathrm{T}^{\mathrm{Hi}}$ subgroup of patients (Figure 5D-E). However, these findings could not be confirmed using univariate and multivariate Cox proportional hazard analysis, potentially reflecting a limited follow-up period, the small size of the patient cohort, disease subset and/or inter-patient heterogeneity. Thus, the precise prognostic value of CRT exposure on AML blasts and NKGD2 levels on NK cells remains to be validated in independent patient series.

Taken together, our results support the association of CRT with enhanced activation of the innate and adaptive anticancer immunity. Parallel assessment of CRT exposure on malignant blasts and immune cell parameters, such as NK-cell markers, may provide prognostic information and have therapeutic relevance for $\mathrm{AML}$ patients in the future.

\section{Funding}

This study was exclusively sponsored by Sotio, Prague, Czech Republic.

\section{Acknowledgments}

The authors thank Anna Fialova for her valuable help with statistical analysis and to Jana Bieblova for help with FACS and ELISA analysis. LG is supported by a Breakthrough Level 2 grant from the US Department of Defense (DoD), Breast Cancer Research Program (BRCP) (\#BC180476P1), by the 2019 Laura Ziskin Prize in Translational Research (\#ZP-6177, PI: Formenti) from the Stand Up to Cancer (SU2C), by a Mantle Cell Lymphoma Research Initiative (MCL-RI, PI: Chen-Kiang) grant from the Leukemia and Lymphoma Society (LLS), by a startup grant from the Dept. of Radiation Oncology at Weill Cornell Medicine (New York, NY, USA), by a Rapid Response Grant from the Functional Genomics Initiative (York, NY, USA), by industrial collaborations with Lytix (Oslo, Norway) and Phosplatin (York, NY, USA), and by donations from Phosplatin (York, NY, USA), the Luke Heller TECPR2 Foundation (Boston, USA) and Sotio a.s. (Prague, Czech Republic).

\section{References}

1. Fucikova J, Moserova I, Truxova I, et al. High hydrostatic pressure induces immunogenic cell death in human tumor cells. Int J Cancer. 2014;135(5):1165-1177.

2. Galluzzi L, Buque A, Kepp O, Zitvogel L, Kroemer G. Immunogenic cell death in cancer and infectious disease. Nat Rev Immunol. 2017;17(2):97-111.

3. Spisek R, Charalambous A, Mazumder A, Vesole DH, Jagannath S, Dhodapkar MV. Bortezomib enhances dendritic cell (DC)mediated induction of immunity to human myeloma via exposure of cell surface heat shock protein 90 on dying tumor cells: therapeutic implications. Blood. 2007;109(11): 4839-4845.

4. Vanpouille-Box C, Demaria S, Formenti SC, Galluzzi L. Cytosolic DNA sensing in organismal tumor control. Cancer Cell. 2018;34(3):361-378.

5. Galluzzi L, Chan TA, Kroemer G, Wolchok
JD, Lopez-Soto A. The hallmarks of successful anticancer immunotherapy. Sci Transl Med. 2018;10(459)

6. Garg AD, Vandenberk L, Fang $S$, et al. Pathogen response-like recruitment and activation of neutrophils by sterile immunogenic dying cells drives neutrophilmediated residual cell killing. Cell Death Differ. 2017;24(5):832-843.

7. Mehta MM, Weinberg SE, Chandel NS. Mitochondrial control of immunity: beyond ATP. Nat Rev Immunol. 2017; 17(10):608-620.

8. Krysko DV, Garg AD, Kaczmarek A, Krysko O, Agostinis P, Vandenabeele P. Immunogenic cell death and DAMPs in cancer therapy. Nat Rev Cancer. 2012; 12(12):860-875.

9. Fucikova J, Becht E, Iribarren $\mathrm{K}$, et al. Calreticulin Expression in human non-small cell lung cancers correlates with Increased accumulation of antitumor immune cells and favorable prognosis. Cancer Res. 2016; 76(7):1746-1756.
10. Fucikova J, Truxova I, Hensler M, et al Calreticulin exposure by malignant blasts correlates with robust anticancer immunity and improved clinical outcome in AML patients. Blood. 2016;128(26):3113-3124.

11. Peng $R Q$, Chen $Y B$, Ding $Y$, et al. Expression of calreticulin is associated with infiltration of T-cells in stage IIIB colon cancer. World J Gastroenterol. 2010;16(19): 2428-2434.

12. Wemeau M, Kepp O, Tesniere A, et al. Calreticulin exposure on malignant blasts predicts a cellular anticancer immune response in patients with acute myeloid leukemia. Cell Death Dis. 2010;1:e104.

13. Fucikova J, Moserova I, Urbanova L, et al. Prognostic and predictive value of DAMPs and DAMP-associated processes in cancer. Front Immunol. 2015;6:402.

14. Lopez-Soto A, Gonzalez S, Smyth MJ, Galluzzi L. Control of metastasis by NK cells. Cancer Cell. 2017;32(2):135-154.

15. Gehrmann M, Schonberger J, Zilch T, et al Retinoid- and sodium-butyrate-induced 
decrease in heat shock protein 70 membrane-positive tumor cells is associated with reduced sensitivity to natural killer cell lysis, growth delay, and altered growth morphology. Cell Stress Chaperones. 2005;10(2):136146.

16. Gross C, Holler E, Stangl S, et al. An Hsp70 peptide initiates NK cell killing of leukemic blasts after stem cell transplantation. Leuk Res. 2008;32(4):527-534.

17. Multhoff G, Pfister K, Botzler C, et al. Adoptive transfer of human natural killer cells in mice with severe combined immunodeficiency inhibits growth of Hsp70expressing tumors. Int J Cancer. 2000; 88(5):791-797.

18. Gastpar R, Gehrmann M, Bausero MA, et al. Heat shock protein 70 surface-positive tumor exosomes stimulate migratory and cytolytic activity of natural killer cells. Cancer Res. 2005;65(12):5238-5247.

19. Vulpis E, Cecere F, Molfetta R, et al. Genotoxic stress modulates the release of exosomes from multiple myeloma cells capable of activating NK cell cytokine production: Role of HSP70/TLR2/NF-kB axis. Oncoimmunology. 2017;6(3):e1279372.

20. Oiu Y, Yang J, Wang W, et al. HMGB1-promoted and TLR2/4-dependent NK cell maturation and activation take part in rotavirusinduced murine biliary atresia. PLoS Pathog. 2014;10(3):e1004011.

21. Panaretakis T, Kepp O, Brockmeier U,
Tesniere A, Bjorklund AC, Chapman DC, et al. Mechanisms of pre-apoptotic calreticulin exposure in immunogenic cell death. EMBO J. 2009;28(5):578-590

22. Zingoni A, Fionda C, Borrelli C, Cippitelli M, Santoni A, Soriani A. Natural killer cell response to shemotherapy-stressed cancer cells: role in tumor immunosurveillance. Front Immunol. 2017; 8:1194.

23. Degli-Esposti MA, Smyth MJ. Close encounters of different kinds: dendritic cells and NK cells take centre stage. Nat Rev Immunol. 2005;5(2):112-124.

24. Van den Bergh JM, Lion E, Van Tendeloo VF, Smits EL. IL-15 receptor alpha as the magic wand to boost the success of IL-15 antitumor therapies: The upswing of IL-15 transpresentation. Pharmacol Ther. 2017;170:73-79.

25. Costello RT, Fauriat C, Sivori S, Marcenaro E, Olive D. NK cells: innate immunity against hematological malignancies? Trends Immunol. 2004;25(6):328-333.

26. Delahaye NF, Rusakiewicz S, Martins I, et al Alternatively spliced NKp30 isoforms affect the prognosis of gastrointestinal stromal tumors. Nat Med. 2011;17(6):700-707.

27. Khaznadar Z, Boissel N, Agaugue S, et al Defective NK Cells in Acute myeloid leukemia patients at diagnosis are associated with blast transcriptional signatures of immune evasion. J Immunol. 2015;195(6): 2580-2590.

28. Kroemer G, Senovilla L, Galluzzi L, Andre F,
Zitvogel L. Natural and therapy-induced immunosurveillance in breast cancer. Nat Med. 2015;21(10):1128-1138.

29. Pasero C, Gravis G, Granjeaud S, et al Highly effective NK cells are associated with good prognosis in patients with metastatic prostate cancer. Oncotarget. 2015;6(16): 14360-14373

30. Galluzzi L, Yamazaki T, Kroemer G. Linking cellular stress responses to systemic homeostasis. Nat Rev Mol Cell Biol. 2018;19 (11):731-745.

31. Fuertes MB, Woo SR, Burnett B, Fu YX Gajewski TF. Type I interferon response and innate immune sensing of cancer. Trends Immunol. 2013;34(2):67-73.

32. Mattei F, Schiavoni G, Belardelli F, Tough DF IL-15 is expressed by dendritic cells in response to type I IFN, double-stranded RNA, or lipopolysaccharide and promotes dendritic cell activation. J Immunol. 2001 167(3):1179-1187.

33. Chen X, Fosco D, Kline DE, Kline J. Calreticulin promotes immunity and type interferon-dependent survival in mice with acute myeloid leukemia. Oncoimmunology. 2017;6(4):e1278332.

34. Han B, Mao FY, Zhao YL, et al. Altered NKp30, NKp46, NKG2D, and DNAM-1 expression on circulating NK cells is associated with tumor progression in human gastric cancer. J Immunol Res. 2018;2018: 6248590 